\title{
How Complaining Customers Make Companies Listen and Influence Product Development
}

Christiansen, John K.; Gasparin, Marta; Varnes, Claus; Augustin, Ina

\author{
Document Version \\ Accepted author manuscript \\ Published in: \\ International Journal of Innovation Management
}

DOI:

$10.1142 / \mathrm{S} 1363919616500018$

Publication date:

2016

License

Unspecified

Citation for published version (APA):

Christiansen, J. K., Gasparin, M., Varnes, C., \& Augustin, I. (2016). How Complaining Customers Make Companies Listen and Influence Product Development. International Journal of Innovation Management, 20(1), [1650001]. https://doi.org/10.1142/S1363919616500018

Link to publication in CBS Research Portal

\section{General rights}

Copyright and moral rights for the publications made accessible in the public portal are retained by the authors and/or other copyright owners and it is a condition of accessing publications that users recognise and abide by the legal requirements associated with these rights.

\section{Take down policy}

If you believe that this document breaches copyright please contact us (research.lib@cbs.dk) providing details, and we will remove access to the work immediately and investigate your claim.

Download date: 26. Apr. 2023

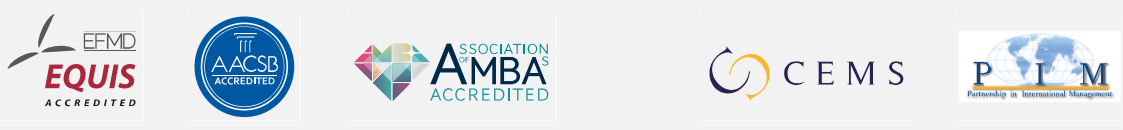




\title{
How Complaining Customers Make Companies Listen and Influence Product Development
}

\author{
John K. Christiansen, Marta Gasparin, Claus Varnes, and Ina Augustin \\ Journal article (Post print version)
}

Electronic version of an article published as International Journal of Innovation

Management, Vol. 20, No. 1, २०16.

DOI: http://dx.doi.org/10.1142/\$1363919616500018

(C) World Scientific Publishing Company.

http://www.worldscientific.com/worldscinet/ijim

Uploaded to Research@CBS: September २०16 


\title{
HOW COMPLAINING CUSTOMERS MAKE COMPANIES LISTEN AND INFLUENCE PRODUCT DEVELOPMENT
}

\author{
John K. Christiansen a , Claus J. Varnes ${ }^{\Omega}$ and Marta Gasparin ${ }^{\Delta}$ \\ with the assistance of Ina Augustin \\ ${ }^{\mathrm{a} \Omega}$ Copenhagen Business School \\ Department of Operations Management \\ Solbjerg Plads 3 \\ DK-2000 Frederiksberg \\ Denmark \\ $\&$ \\ ${ }^{\Delta}$ Leicester University \\ School of Management \\ Ken Edwards Building \\ University Road \\ Leicester, LE1 7RH \\ UK \\ *Corresponding author: johnc@cbs.dk
}




\begin{abstract}
The analysis in this paper shows how complaining customers can make companies listen to them by spurring the mobilization of various actors into a hybrid collective strong enough to influence companies' product development. Customers as sources of innovation have been analysed previously in the literature, whereas the process of how complaining users mobilize support to influence companies has received less attention and is not well understood.
\end{abstract}

This study uncovers the processes that made it possible for a 17-year-old Norwegian to become pivotal in constructing a problematization, which emerged to become so strong as to alter the Norwegian Coca-Cola Company's earlier decision to cease production of a product in a certain size. The analysis uses constructs from actor-network theory and shows how a single dissatisfied individual was able to become a spokesperson who, through different processes, mobilized a heterogeneous group of consumers into a loosely connected hybrid collective. The spokesperson acted on behalf of the hybrid collective and put growing pressure on a multinational company, influencing its decision making. In this case, the complaining customer did not exit, nor did he become a lead user, but rather became a hybrid customer who actively tried to mobile others in his desire for a product.

The study reports on a process analysis of the means by which the company was induced to reinstate a discontinued product. The analys is is divided into three episodes, each marking a critical phase for the collective. This opens up the way for an examination of the processes of mobilization, interessement, enrolment and mobilization, revealing the margins of manoeuvre and how these are negotiated and delimited in the process.

Keywords: Complaints; Users; Product Development; Actor-Network Theory, Hybrid Collective 


\section{INTRODUCTION}

The involvement of users in new product development focuses on the identification of customer needs, lead users, community approaches and co-creation techniques (e.g. Baron and Warnaby, 2011; Calantone et al., 1995; Chassagnon and Audran, 2011; Fuchs and Schreier, 2011; von Hippel, 1978, 1986), but very little attention has been devoted to users who complain in innovation research (Schumacher and Kuester, 2012; Ward and Orstrom, 2006). A systematic search in the Ebsco database, performed in May 2014, with the keywords "complaining and innovation", "complaints and innovation", "complaining and product development" and "complaints and product development", provided no unique result within the innovation management domain. Continued searches within the main journals of innovation management from the 2011 ABS list yielded no results that included the aspect of innovating by involving complaining users.

However, the issue of dissatisfied customers' reactions in general was treated as early as 1970 by Albert O. Hirschman, who made a basic distinction between two alternative ways of reacting to deterioration in business firms and to dissatisfaction with organizations in general: the first option, "exit", is for the customer to switch to a competing product; the other option, "voice", is for customers to agitate and exert influence for change. Hirschman was, among other things, concerned with how to create the right balance between the two types of reaction (Hirschman, 1970).

Subsequently, research within the area of marketing and sales on complaining customers has dealt with the role of customers in innovation, namely the role of lead users, co-creation and co-construction, addressed below. However, although prior research has studied how customers could be involved in new product development (Brockhoff, 2003), the process of how dissatisfied customers are mobilized and gain influence is not well understood. This paper explores the strategies of complaining users in their attempts to involve others, the mobilizations used and the final "interessement" of the company to change prior decisions and strategies and open itself up to the involvement of the complaining customers.

For this purpose, an exploratory research study (Daymon and Holloway, 2011; Yin, 2009) was regarded as pertinent as it is an approach that allows researchers to gain in-depth insight into an unexplored research topic. The analysis in this research is based 
on a study of a series of episodes around "Urge", a soda beverage. Originally introduced in the Norwegian market as a test product, Urge was launched in 1996. This Norwegian carbonated soft drink was also launched in Denmark, Sweden and the United States, but was withdrawn after a short period. Norway is the only country that produces and markets Urge today.

Urge was originally introduced to customers in two quantities, 0.5 litre and 1.5 litre, with varying commercial success. The company decided to withdraw the 1.5 litre bottle from the market in 1998 because it proved to be unprofitable. Not knowing that the 1.5 litre bottle had previously been on the market, Magnus Nyborg from Bergen experienced a need for a larger volume. He founded a group on Facebook to interest more actors in the goal of having a larger bottle. Magnus soon gained many supporters and he started to involve the press and the Coca-Cola user forum. Coca-Cola eventually decided to involve him in the launch of a 1.5 litre bottle of Urge and subsequently in the process of developing a new soft drink launched later under the name Urge Intense.

The analysis of these dynamics draws upon theories from the sociology of science and technology (Callon and Law, 1982; Latour, 1987) and is based on the study of translation, mobilization, enrolment and struggle (Callon, 1986a, 1986b) in line with a recent stream of research in the innovation management literature (Akrich et al, 2002a, 2002b; Christiansen and Varnes, 2007; Christiansen et al., 2009, 2010). The study analyses the mechanisms used to translate and mobilize by creating a hybrid collective in the quest to make the company listen. The analysis applies the theory of translation with its four moments and the use of obligatory passage points (Callon, 1986b). This analytical framework is used to analyse three episodes identified in the process.

The remainder of this paper is structured as follows: first, the role of customers in new product development is discussed with respect to complaints, lead users, co-creation and co-constructivism. Second, methodological considerations are discussed with a presentation of the theory of translations. Third, the analys is of the case is conducted for three episodes with a sequence of translations. Finally, the analysis is discussed and followed by a conclusion with implications for research and practice.

\section{THE ROLE OF CUSTOMERS IN NEW PRODUCT DEVELOPMENT}




\section{Complaints Management}

Building on the concepts of Hirschman (1970), Fornell and Wernerfelt (1987, 1988) suggested that companies should strive to maximize the number of complaints to collect valuable insights from dissatisfied customers. A simulation shows how the use of intelligent customer complaint management, which makes it possible to recover otherwise lost customers, leads to increased profit if the volume of complaints increases (Fornell and Wernerfelt, 1988, p. 297). Customers who decide not to raise their voice cannot be recovered; thus, explicit customer complaints are a potential source of wealth for companies. These ideas have spurred research on complaints management within marketing (Anderson et al., 1994) and on how to exploit voices from dissatisfied customers to improve products and services (Jeppesen, 2005; Lagrosen, 2005), for example by having processes and systems in place to collect and handle complaints (Homburg and Fürst, 2005; Jeppesen, 2005; Zairi, 2000) and having complaint managers (Stauss and Schoeler, 2004).

Complaining customers are those who are dissatisfied with a product or a service and clearly state it. However, consumers have several choices when a service failure is experienced: switching to a competitor, complaining to the seller, complaining to a third party, using negative word-of-mouth, or simply doing nothing and resolving to be satisfied with a less than desirable level of service quality (Goetzinge et al., 2006; Schuhmacher and Kuester (2012) suggest companies should make use of their complaint database to invite dissatisfied users to participate in idea contests. It is not only ensuring customer satisfaction that is important for companies, but also dissatisfaction management and complaints treatment (Hansen et al., 2010; Plymire, 1991) and complaint management permits companies to satisfy and retain customers (Hart et al., 1990). However, analysis of a large sample of retailers shows very different approaches and attitudes towards customers' complaints (Hansen et al., 2010).

Ward and Ostrom (2006) have investigated the behaviour of complaining customers who are active in creating websites to stimulate negative word-of-mouth regarding a company. The behaviour of such complaining users in starting the process and investing time and resources in complaining so explicitly is explained by their desire 
to amplify their voice: they are angry with service or product failures followed by ignored complaints and thus feel betrayed by the company (Ward and Ostrom, 2006). Betrayed customers who warn other consumers against a misbehaving firm tend to present commercial failures as examples of a betrayal of customer rights. They amplify the seriousness of the harm, stereotype firm executives as evil betrayers, post complaints of other consumers on the website, present themselves as crusaders and motivate other consumers to consider themselves part of a group against the firm, suggesting that when dissatisfied consumers find one another, their interaction may reinforce their antipathy towards a firm (Ward and Ostrom, 2006).

\section{Lead Users}

Whereas complaining users state their dissatisfaction with products or services, lead users propose a solution to an unmet need (von Hippel, 1978). Following von Hippel (1978, 1986), lead users develop and materialize an idea and subsequently propose it to a manufacturer, becoming small entrepreneurs. Von Hippel (1978) proposed a shift from a so-called "manufacturer active paradigm" towards a "customer active paradigm".

The manufacturer active paradigm entails that manufacturers recognize the necessity of introducing a new product. They then decide to investigate which needs are not yet satisfied and potential future trends, involving customers through surveys. The customers are defined essentially as respondents, speaking only when spoken to, whereas the manufacturer is active in selecting and surveying a group of customers to obtain information, analysing the data, developing a responsive product idea and testing it using customer perceptions and purchase decisions (von Hippel, 1978, p. 40).

The customer active paradigm proposes the emergence of the concept of lead users, who are described as customers with an active role in proposing a product or a solution they need to a manufacturer and selecting a supplier capable of producing the product. Here, the role of the manufacturer is to wait for the potential customers to submit a request, to screen ideas for new products and to select those that seem to offer greater promise from the manufacturer's point of view for development (von Hippel, 1978). From this paradigm, the notion of lead users was developed: a lead user is a customer who will engage in innovation himself or herself when faced with a problem, 
initiating a problem solving process and developing working prototypes (von Hippel, 1978). Lead users are defined as those who "face needs that will be general in a marketplace - but face them months or years before the bulk of that marketplace encounters them, and lead users are positioned to benefit significantly by obtaining a solution to those needs" (von Hippel, 1986, p. 796).

\section{Co-creation}

Co-creation is a situation in which interaction is facilitated between the manufacturer and the customers. Co-creation involves working actively and together with customers to enhance the value they obtain and it is aimed at understanding the customer needs to reduce the risks inherent in innovation; in the literature of innovation management, cocreation is described as a tool to accelerate innovation. Part of the research on co-creation is related to virtual environments as new technologies make it possible to involve resourceful customers in the co-creation of new solutions (Nambisan, 2002; Sawhney and Prandelli, 2000).

Customers in the co-creation literature are considered contributors to the new product development process, both in the product design phase and in development activities, including the design, the prioritization of product features and the specification of product interface requirements (Nambisan, 2002). Companies applying this approach experience a more active engagement from customers in their product development processes than those engaging in traditional market research (Sawhney and Prandelli, 2000) by involving customers in value creation processes to sustain the pace of innovation from fast-changing technologies and customer needs (Leonard-Barton, 1995).

The Internet is used as a tool to co-create new products and customers are engaged to contribute their creativity and problem-solving skills:

[...] by generating and evaluating new product ideas, elaborating a detailed product concept, evaluating or challenging it, discussing and improving optional solution details, selecting or individualizing the preferred virtual prototype, testing and experiencing the new product features by running simulations, getting information about the new product or just consuming it. (Füller and Matzler, 2007, p. 381) 
This is also interpreted as empowerment of the customers (Bilgram et al., 2008; Fuchs and Schreier, 2011).

The motivations for customers to engage in co-creation are a combination of intrinsic and extrinsic factors (Füller and Matzler, 2007). Users' motives differ, are heterogeneous and can be divided into segments of motivation. Füller and Matzler (2007) find that reward-oriented consumers are highly motivated to engage in virtual co-creation and have a desire for monetary rewards; need-driven consumers participate because they are dissatisfied with existing product solutions; curiosity-driven consumers are driven by their curiosity; intrinsically interested consumers are motivated by the innovation activity and are not stimulated by monetary reward.

\section{Co-construction perspective}

The co-construction perspective - based on the notion of actor-network theory (ANT) - focus on the interplay between different actors, both human and non-human, with equal constitutive characteristics (Latour, 1987). The focus is on relationships and networks, rather than the interpretation of any meaning or any particular person's interpretation.

The actor network is reducible neither to an actor alone nor to a network. (...) An actor network is simultaneously an actor whose activity is networking heterogeneous elements and a network that is able to redefine and transform what it is made of. (Callon, 1987, p. 87)

Regarding innovation, this view takes account of the fact that innovation tends not to move through distinct phases with clearly separated activities and roles, but is better characterized by many processes happening at the same time and where "the user, as well as all the intermediaries" (Callon, 2004) participate in the innovation (Akrich et al., 2002a, 2002b; Christiansen and Varnes, 2007; Christiansen, et al., 2009, 2010; Latour, 1987). This mixing of roles and the constant interaction in the design and use of products and services is characterized as "hybridization" between design, innovation and use by Callon (2004, p. 3). Furthermore, innovation is considered an ongoing process that does not stop when the product is launched on the market as the value of products depends on the extent to which customers are attached to or detached from products and services, which might change over time (Christiansen et al, 2010). Products and services are in 
constant search of allies as their attractiveness determines their value and more relationships means stronger relations and higher value (Callon et al, 2002). Thus, the value of products and services is in the hands of the customers and the relationships between these are considered fragile and constantly negotiated (Akrich et al., 2002a). As consumers' perceptions and actions influence the fate of products, the process of maintaining the attractiveness of products and services is never-ending from the perspective of companies:

[It] is a never-ending process. Goods and services have a social life; they go from hand to hand and change along the way. Each actor involved reconfigures and reshapes them depending on her needs and conceptions. Adopting and innovation means adapting it. (Callon, 2004, p. 3)

The never-ending, constant reconfiguration of products and services by both human and non-human actors within this hybrid process happens through or is influenced by - and in some instances driven by - collaborative communities (Knorr Cetina, 1999), in this context understood as hybrid collectives (Callon, 2004, p. 4) as they are a mix of heterogeneous human and non-human actors.

This perspective also points to the fact that innovation is not considered an isolated concept derived from the individual, but emerges through the collective: it is the collective that invents, designs, develops and uses innovation (Callon, 2004, p. 4). Nonhuman actors can be various IT-based platforms in which information, complaints and views concerning products, services and companies are exchanged, ideas are generated, discussions take place and networks of human and non-human actors are created and stabilized; in these ways, such platforms and fora "actively participate in the production of the social" (Callon, 2004, p. 6). Knowledge and action are never individual; cognition is distributed between humans and non-humans, participating in the enterprise of knowledge creation or in action (Callon and Muniesa, 2005, p. 1237; Knorr Cetina, 1999). Actors, users or consumers are not isolated. The social ICT-based media provide a platform for actors to create an open collective in which users, amongst others, can establish consumer products. ICT connects actors and shapes the composition of societies (Akrich, 1992; Akrich and Lemonnier, 1993). Time and space become irrelevant within 
the collective as information can be shared at any time with actors from anywhere in the world (Callon, 2004; Latour, 1987).

Hybrid collectives can be found everywhere (Callon, 2004, p. 4) as open source communities within computing, patient groups, citizens who fight for environmental issues, citizens who want or are against new highways, consumers working for or against specific companies or products and so on. These collectives do not follow normal organizational structures or boundaries. They are cosmopolitan and are constituted by heterogeneous users, located in different places, having different motives and preferences, norms and values, being of different ages and sexes, and can potentially consisting of specialists and professionals (Knorr Cetina, 1999).

Some collectives are structured and even hierarchical, as in the sciences, whereas others, such as user communities and citizens action groups, are loosely connected and might exist only in the virtual world. The communities are flexible, organic, shifting and adapting to whatever attracts the attention of the members. Some collectives might only exist for a short time; others live on for many years or even centuries. Most of these hybrid collectives are highly dependent on and actually formed by and around communication technologies that provide an opportunity to present, announce, facilitate and communicate across space. Furthermore, adding to the definitions proposed by Callon (2004), we would suggest that the role of membership is a negotiable issue in the collectives. In some hybrid collectives the membership is regulated and can be based on formal requirements, such as a certain type or level of education, position in society, or a special requisite contribution - e.g. payment of fees - to the collective. In others, as in a user action group, membership is open to all who are interested and anyone can sign up, $\log$ in or attach themselves to the community. The enrolment of actors is described as a process of translation in this view (Callon, 1986a; Latour, 1987).

\section{Enrolment and translation}

The attractions of new allies, or the processes of enrolling actors, are described by the principle of translation in the co-construction perspective we apply here. Attachment is described as a translation process that happens though four processes or movements: problematization, interessement, enrolment and mobilization (Callon, 1986a, 1986b; 
Latour, 1987). These processes are not necessarily sequential, but can happen simultaneously (Latour, 2005). This perspective has been used in the studies in innovation management (Akrich et al., 2002a, 2002b; Christiansen and Varnes, 2007; Christiansen et al., 2009, 2010).

Enrolment is successful when the enroller is able to displace the interests of the enrolled, instead of the enroller's own interests. The enrolment process ensures the creation of a new network through the process of translation. By enrolling other actors and making them interested and part of the network, an actor becomes a legitimate spokesperson and can speak on behalf of other actors (Callon, 1986b). The role of the spokesperson and his/her authority is negotiable and is based on acceptance from other actors. Translated (enrolled) actors can have multiple interests, disagree or even reject the project proposed by the spokesperson; this can convert the translation into an act of "treason" (Callon, 1986a). The analysis is conducted by using the concept of translation as formulated by Callon in his model with four moments of translation and obligatory passage points (OPPs) (Callon, 1986a).

This is not an interpretive theory claiming that reality is a personal or social construction inside one or more person's heads, but regards reality as constructed by the interplay of human and non-human actors; the focus is on the relations. What holds this fragile (Latour, 1987) actor world together? What brings actors together and how are these constructions made stable and what are the threats?

\section{RESEARCH METHODOLOGY}

Traditionally, case studies are recommended to investigate contemporary events in reallife contexts (Daymon and Holloway, 2011; Yin, 2009) to enable the researcher to collect rich and detailed information across a wide range of dimensions about a particular case (Daymon and Holloway, 20011. However, the traditional case approach needs to be expanded and modified - or maybe even abandoned - in order to suit ANT and its focus on relationships (Callon, 1987). The notion of studying "events" in "a real-life context" becomes problematic if the construction of the world is not to be separated from the elements themselves and their parts: the social and the technical elements that constitute the network (world). The production of the accounts of actors, actions and associations, 
the recording and the subsequent ordering of elements, the presentation of connections and the carefully written narrative represents the duality in ANT: the classification and ordering of elements $\underline{\text { is }}$ the analysis and the production of text and narratives is the study. As Latour (2005, p. 122) puts it, 'We write texts, we don't look through some window pane".

Latour asks researchers to follow the actors (2005, p. 12) and we can add that we also need to follow the connections - what they are and what they do - the modifications and changes that happen when new actors are added or taken away from the network and how these connections are established. In a somewhat hesitant definition of what constitutes "good" research from this perspective, Latour (2005, p. 128) states, "A good ANT account is a narrative or a description or a proposition where all the actors $d o$ something and don't just sit there" (emphasis in the original).

This paper examines an interesting case brought to the attention of the authors by the social media. The story was about a Norwegian complaining customer - Magnus Nyborg - who liked something so much that he needed more of it. Magnus wanted the energy drink "Urge" in a bigger 1.5 litre bottle, but could not get it: it was sold only in 0.5 litre quantities. The larger bottles were taken off the market many years before in 1999 due to very low sales volumes. Magnus co-created a hybrid collective that eventually managed to persuade the Norwegian Coca-Cola Company to (re)launch the 1.5 litre bottle of Urge.

The case is interesting for two reasons: Specifically because it is apparently - on the surface - about the single boy against a multinational corporation. The underdog that successfully - against all odds - fights and wins the battle. But, even more interesting, this case is about how an underdog wins because he is able to mobilize human- and nonhuman allies, and construct a hybrid collective. Magnus became a spokesperson for Urge, empowered by the hybrid collective and their actions, which show that social media can be more than just verbal utterances. The company even later involved him as a spokesperson in developing a new product: Urge Intense.

To investigate the case further data were collected through interviews and secondary data, such as newspaper articles, blogs and posts from the Facebook group, to triangulate the evidence. The case was first researched through searches on the 
worldwide web using a multitude of sources, such as online fora, newspapers and a collection of anecdotal evidence. Seven interviews were conducted with participants involved in the Urge case, both from the consumer and the company side. Secondary sources were used to trace the actors involved through pyramid sampling to ensure the legitimacy of the respondent initially identified (Lilien et al., 2002). Interviews were conducted in two different countries and four different cities, as reported in Table 1. The interviews were conducted using a semi-structured interview protocol (Daymon and Holloway, 2011. It was assumed that the episodes would be perceived differently from the perspective of consumers and that of the firm; thus, two different interview protocols were prepared. During the interviews, three co-constructivist principles were applied: agnosticism (gaining understanding of the actors' point of view), generalized symmetry (applying the same vocabulary to human and non-human actors) and free association abandoning all distinctions between natural and social events (Callon, 1986a, 1986b). In total, one researcher spend five weeks in Norway interviewing, observing, collecting data using street interviews and taking to customers who considered purchasing or did actually purchase bottles of Urge.

Table 1: Overview of data collection.

\begin{tabular}{|l|l|l|l|l|}
\hline \multicolumn{1}{|c|}{ Position } & \multicolumn{1}{|c|}{ Location } & \multicolumn{1}{c|}{ Date } & How & \multicolumn{1}{c|}{ Time } \\
\hline $\begin{array}{l}\text { European Creative Director, } \\
\text { The Coca-Cola Company }\end{array}$ & Hellerup, Denmark & $08 / 02 / 2011$ & Personal & $39 \mathrm{~min}$ \\
\hline $\begin{array}{l}\text { Director of PR and } \\
\text { Communications, Coca- } \\
\text { Cola Nordic Aps }\end{array}$ & Hellerup, Denmark & $01 / 04 / 2011$ & Personal & $1: 02 \mathrm{~h}$ \\
\hline Founder Facebook group & Bergen, Norway & $15 / 04 / 2011$ & Personal & $1: 15 \mathrm{~h}$ \\
\hline $\begin{array}{l}\text { Norway Market Operations } \\
\text { Manager, Coca-Cola } \\
\text { Norway }\end{array}$ & $\begin{array}{l}\text { Loerenskog, } \\
\text { Norway }\end{array}$ & $28 / 04 / 2011$ & Personal & $50 \mathrm{~min}$ \\
\hline $\begin{array}{l}\text { Communications VP, Coca- } \\
\text { Cola Enterprises Norway } \\
\text { AS }\end{array}$ & Oslo, Norway & $29 / 04 / 2011$ & Personal & $1: 14 \mathrm{~h}$ \\
\hline $\begin{array}{l}\text { Commercial Manager, } \\
\text { Coca-Cola North West } \\
\text { Europe \& Nordics }\end{array}$ & Oslo, Norway & $29 / 04 / 2011$ & Personal & $35 \mathrm{~min}$ \\
\hline Founder Facebook group & Virtual & $12 / 05 / 2011$ & E-mail & 2 days \\
\hline
\end{tabular}


The interviews were recorded, fully transcribed and coded using NVivo-10 according to the theoretical framework presented by Callon (1986b) and adapted for use here. The analysis was divided into three episodes or moments in which the translation processes were analysed. The choice of the moments was based on three criteria: (1) the stability of the existing situation was challenged by some actors entering the network or leaving the network; (2) the status quo was considered to be challenged by those interviewed; (3) a change occurred and a new network constellation was established. The three translations analysed were: i) Urge in a bigger bottle; ii) the day of the Urge; iii) new product initiated. With the analysis of three consecutive translations, it is possible to show how the translation process transforms and the translations "become a bifurcation, an event or the origin of a new translation" (Latour, 2005, p. 128). This perspective is surely one of emerging, negotiating and fragile associations with a "string of actions where each participant is treated as a full-blown mediator" (Latour, 2005, p. 128).

Following Callon (1986b), a translation process that leads to the interessement and enrolment of actors in a network consists of four movements: 1) problematization, (2) interessement, (3) enrolment and (4) mobilization. In this framework, both human and non-human actors are considered semiotic entities with agency in a process in which a spokesperson tries to persuade - using problematization - the actors to enter what Callon (1986b) calls the obligatory passage point (OPP) of the spokesperson through the four moments of translation. This expresses the core idea that the spokesperson - through more or less complex negotiations, persuasion and evidence of the potential benefits to them - induces actors to change their course of action and enter the OPP, thus supporting the desired objectives of the spokesperson. The problematization is the identification of a system of alliances, or associations between entities (Callon, 1986b, p. 369) that must be constructed in order to achieve specific goals. Problematization thus represents what is declared necessary or needs to be achieved, the actors involved, their role (identities) and what detours actors need to make to achieve the goal(s) by passing through the OPP (Callon, 1986b, p. 205), as shown in Figure 2. Problematization can be considered an attention directing device (Bentzen et al., 2011), which drags the actors in the desired direction, which is the direction that those trying to speak on behalf of others find suitable, relevant or necessary. 


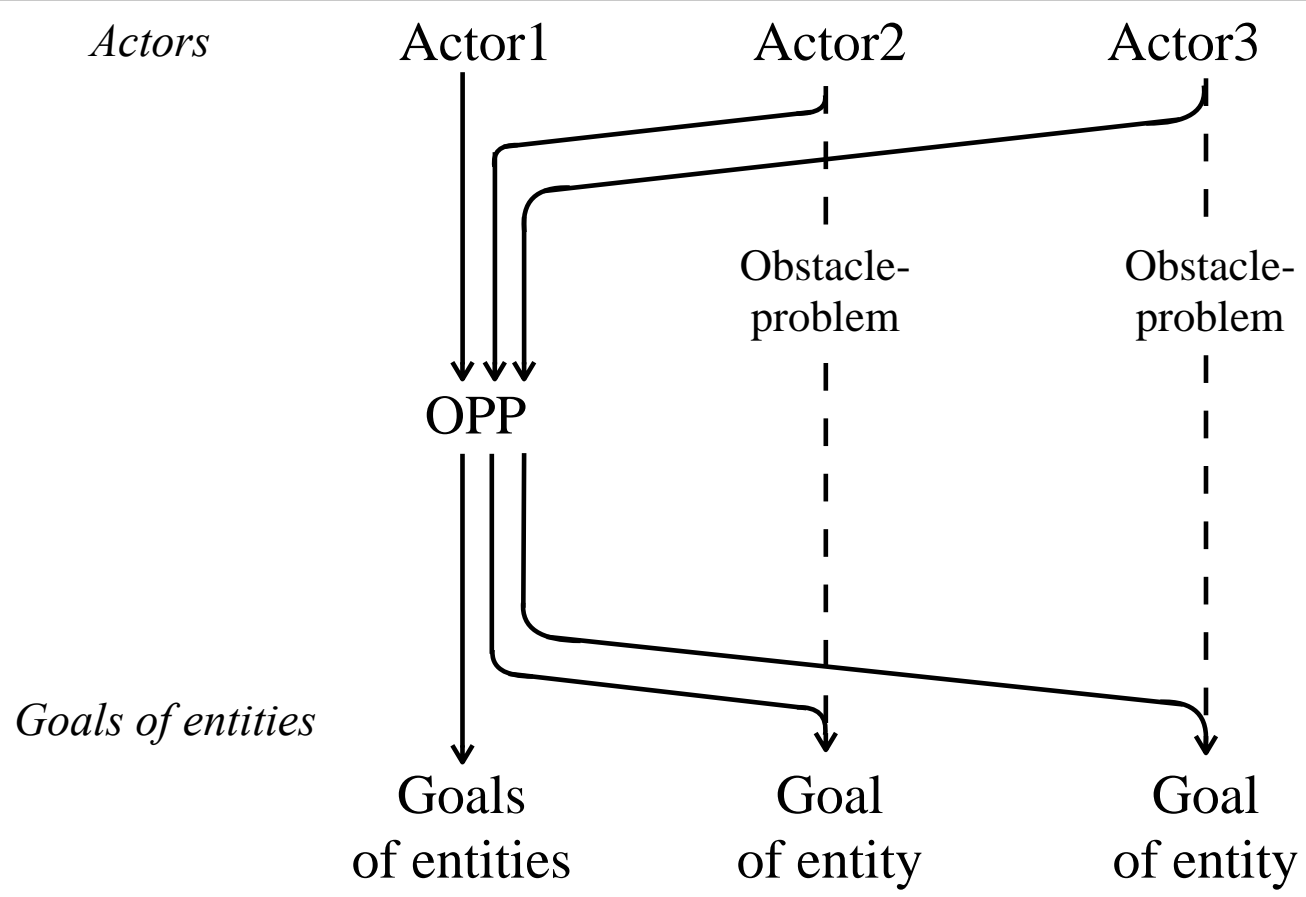

Figure 1: Analytical framework showing successful translation of actors through the OPP (adapted from Callon, 1986b).

As illustrated in Fig. 1, a successful translation process will make actors change their course of action, direct their attention towards the OPP and become part of the same network. The translation process describes how one or several actors try "to impose themselves and their definition of the situation on others" (Callon, 1986b, p. 196). Rather than pursuing their individual goals, actors will be "convinced" to go through and accept the OPP as they accept the problematization that precedes the interessement and enrolment in the network, making mobilization possible.

Progression through the movements and the OPP does not constitute passive adoption or acceptance, simply connecting to the network and another goal, but is a process involving negotiations, struggles and debates on disagreements that - if successful - leads to the acceptance of spokespersons who can talk and act on behalf of the collective (Callon, 1986b). The actors considered spokespersons establish themselves 
and are recognized as indispensable in the network, fostering the translation process (Callon, 1986b).

The analysis of the three episodes of translations here employs the four constructs already introduced, as follows:

- Problematization: What is the concern and goal of the complaining user and what is the argument used to make this something that concerns others and sets out why his concern should also be theirs? The last movement is called a "double movement" that moves the focus from "my" problem to "yours" and from "your" problem to "ours"; this, according to Callon (2004 p. 205), is what creates the OPP.

- Interessement: Following Callon (2004 p. 207) "Interessement is the group of actions by which an entity attempts to impose and stabilize the identity of the other actors... To interest other actors is to build devices [arguments, data, claims, etc.] which can be placed between them and all other entities who want to define their entities otherwise". What are the strategies, arguments and devices used? As the actors are not yet enrolled in the translation process at this point, are there struggles, controversies or resistance?

- Enrolment: The actual forming of alliances happens during enrolment, moving the translation process from a number of proposals, declarations and suggestions to form "statements which are more certain" (Callon, 1986b, p. 211). This includes the acceptance of the fashioned or negotiated roles of actors in the alliance. Enrolment must eventually overcome disputes, struggles and resistance - which can come from anywhere - to settle the alliance. Who or what are the actors enrolled in this movement and how are their roles defined?

- Mobilization of allies: This movement of the translation process concerns how the alliances formed in the enrolment identify spokespersons who are 1) considered legitimate for representing the alliance and 2) successful in their interactions and negotiations for the alliance. The outcome is concerned with the fate of the translation processes and the movements as assessed from the point of view of the initial problematizer 


\section{ANALYSIS OF THE THREE TRANSLATION PROCESSES}

\section{First translation: Urge in a bigger bottle}

\section{Problematization}

Magnus's goal was to be able to purchase a larger volume of his favourite soft drink in 1.5 litre bottles, not only for himself but also for fellow customers, thus expanding the problem to a collective claim for Urge. Magnus expressed his desire to have Urge in 1.5 litre bottles in early 2005 :

We wanted Urge. Not Coke. It kind appealed to me, it was kind of a national thing to me, kind of funny. It sort of appeals to me, when I was a kid, we were skating, hanging out at this local store, me and a bunch of guys from school... we were just hanging around skateboarding and when we were thirsty, we would always buy Urge. The vending machine was always out of Urge, so instead of buying Coke or Fanta, we went to the local store to buy Urge.

The group of friends to which Magnus belonged also wanted the larger sized Urge, even if their motivations were not so clearly formulated:

I don't know, we all felt we liked it and we wanted it back, it was a lifestyle kind of thing. (Member of the group)

This friend's need for a bigger bottle was acute but not enough to prompt him to express an unmet need:

Why did I want it? It has always been an issue constantly going on in my head. Kind of funny, because I've been thinking about it for a very long time: why aren't there any 1.5 litre bottles? I felt I deserved a larger bottle.

\section{Interessement}

The group of friends close to Magnus started an initiative, asking for the 1.5 litre bottle of Urge as a "funny game" and they uploaded old pictures of the Urge bottles on social media such as they used to have in their childhood and early teens. At school, in the media class, they created advertising, pictures and projects for the Urge 0.5 and 1.5 litre bottles. When Facebook started to be used as social media in Norway, they discussed the 
possibility proposed by Magnus to create a page for Urge. Magnus's friends were very supportive of this idea and therefore encouraged him to pursue it.

He decided to create an Urge 1.5 litre bottle Facebook group as he had heard of similar trends for other products ("product back campaigns"). In the beginning, Magnus engaged in the different activities for fun as he was not sure of the outcome of these processes. However, within a very few days, the social media group had more than 100 members. He encouraged his classmates to join the group and they extended the invitation to other friends in the school, partly because they all thought it was funny and partly because Urge represented a lifestyle they wanted back. They all contributed by providing pictures and sharing stories of their skating or snowboarding events related to Urge.

The Coca-Cola Company in Norway noticed the activities of the group when its number of members increased and started to monitor actively the group's discussions and the posts. Coca-Cola Norway informed headquarters in Atlanta of this development. Coca-Cola (The Coca-Cola Company Norway and Coca-Cola Enterprises Norway) was faced with a demand that could not be backed by actual sales numbers. Sales predictions were derived on the basis of surveys and in this case were interpreted as showing no real demand for higher volume bottles. A Facebook group with an uncertain amount of fans could not substantiate a strong argument that there was real demand for the 1.5 litre bottle. In fact, although production of the 1.5 litre bottle had been discontinued in Norway in 1999 due to low sales, the 0.5 litre bottle was still on the market. As a CocaCola representative told us:

...after 1999 the product had just been living its life on its own. No real marketing investment behind it. It just stayed at a 5-10\% market share but in 2005/2006 we saw that there was a sales growth without any marketing behind it and it surprised us. We did some research and we discovered that teenagers perceived it as a retro brand. It was from the 90s, it was considered oldish, but they saw it as kind of cool. We saw that skateboarders and the graffiti environment started to put the bottle in their pockets.

In addition to the lack of hard data, Coca-Cola Norway was sceptical about the wisdom of listening to the demands of social media as management had carried out a risk analysis 
based on health concerns and the Norwegian health regulations. The management of Coca-Cola Norway was concerned about the potential for incurring governmental sanctions due to the high amount of sugar and caffeine in Urge and the target group was mainly teenagers. The teenagers wanted a 1.5 litre bottle because the 0.5 litre bottle was "empty too soon", but Coca-Cola was reluctant and careful not to agree to this proposal because there were health, obesity and sugar debates involved. Coca-Cola decided that it needed to come up with a strategy to deal with this challenge and the 0.5 litre bottle of Urge was considered the right volume to avoid interference from governmental health regulators. Moreover, Coca-Cola Norway needed to consider the potential risk for the local bottler responsible for local distribution. According to the operations manager:

We make our revenues by selling concentrated bottles. So for us, the risk is absolutely minimal. The moment we have convinced them to do something, we have our revenues in the bank. For them, it's a bit more of a risky approach because they need to procure all the related materials, they need to build that into their customer plans and sometimes they even need to pay distinct fees; for them, if a proposition does not fly, they have more costs than rewards. (Operations manager, Coca-Cola Norway)

A reporter, interested in Magnus's project, contacted Coca-Cola and asked how many members in the group the company needed before they would consider it as a serious user group. The answer was that Magnus should double the number of members if he and his group wanted to be taken into consideration. After the interaction with the journalist, Coca-Cola sent Magnus an e-mail stating:

[W]e see that this is a popular project. If the fans on Facebook double the amount of members, we will consider the claim for the product.

However, the decision-making process in Coca-Cola was stalled even after Magnus did actually double the number of social media members as management was divided into two factions: risk vs. no risk. They were impressed by Magnus's capability in doubling the number of group members. Moreover, his activities had a positive impact on sales of the 0.5 litre bottles of Urge, which had been very low for many years. Urge was considered ugly and retro. Suddenly, it was becoming cool and it was Norwegian: Urge was launched in Norway in 1996, as a Norwegian brand, developed in Norway for 
Norwegian preferences. It was a very local brand development as the taste of citrus and cider for unknown reasons seemed to be especially suitable for this market. However, at the same time, it was the product with the highest sugar and caffeine content, not considered healthy and unable to be sold in other countries due to health concerns.

\section{Enrolment}

Magnus successfully enrolled other Urge enthusiasts who joined his Facebook group “URGE PÅ 1.51 FLASKER!'” (Urge on 1.51 bottles). The group responded to the challenge from Coca-Cola and achieved the double number of members in 2.5 days. The 0.5 litre Urge bottle was successfully enrolled in the quest as the demand for and sales of the product kept rising. Some members of the Facebook group founded another group, called "We love Magnus Nyborg" and he was described as a "god" because he demanded that Urge should come back in larger bottles. Numerous messages from members of the group encouraged him to continue with this enterprise. Coca-Cola limited its interactions to observing the activities and responding vaguely to requests received on social media, stating that it was thankful for the interest shown. The company had one person in charge of monitoring activities on the social media and he continued to report the growing interest in the product to senior management. Nevertheless, the enrolment of Coca-Cola failed. The company was concerned by the health trend and continued to question the seriousness of demand expressed through social media activities.

Another argument for Coca-Cola not responding positively was the increase in the market share for the 0.5 litre Urge. The 0.5 litre product had large margins and was becoming even more profitable. In contrast, as the Coca-Cola PR manager remarked, "if we launch a bottle three times bigger, the 1.5 litre, it needs to be sold at a lower price per litre and the (profit) margins will be lower". The company remained doubtful of the relevance or need to change established products based on reactions in social media and it further questioned the need to consider pressure and complaints from this group, arguing that it was only one of approximately 200 groups concerning Coca-Cola products.

Magnus shared the negative message from Coca-Cola with the Facebook group and again the group's members doubled in three days (from 4,276 to 8,560). Magnus started to spam Coca-Cola with provocative mails, indicating the target reached and asking what 
more the company wanted. Did it need more proof to accept that there was a real interest in having 1.5 litre bottles? The number of articles published in the Norwegian newspapers was increasing, describing the actions of Magnus and how the members in the Facebook group were committed to their goal.

\section{Mobilization of allies}

Eventually Magnus mobilized a hybrid collective network that made him a legitimate spokesperson and Coca-Cola accepted him as the spokesperson of the Facebook group, but not as a spokesperson for the wider Urge community. The more the group gained in size, the more Magnus started to encourage other members to complain on the virtual wall discussions of the Facebook group about the lack of availability of a 1.5 litre bottle. According to the group members, the 0.5 litre bottle was too small and "finished much too soon". Magnus commented on this:

It was pretty much for fun; everyone invited their friends who invited their friends. Maybe they were not as passionate as me, but we had the same lifestyle and they saw this group and they thought "Wow I have actually thought about this before myself". And they were like: "Wow, we can do this". I guess I got a lot of members excited in a lot of different ways. That was pretty fun and a lot of people participated and uploaded photos and gave status to me.

Magnus was very active in the group: he frequently wrote to the members and he kept the group updated so the members could feel part of a group that was evolving and progressing. He also initiated action to encourage the members to "spam" Coca-Cola and write on the company forum website the same request that should be copied and pasted every day: "We want Urge back in 1.5 litre bottles". 


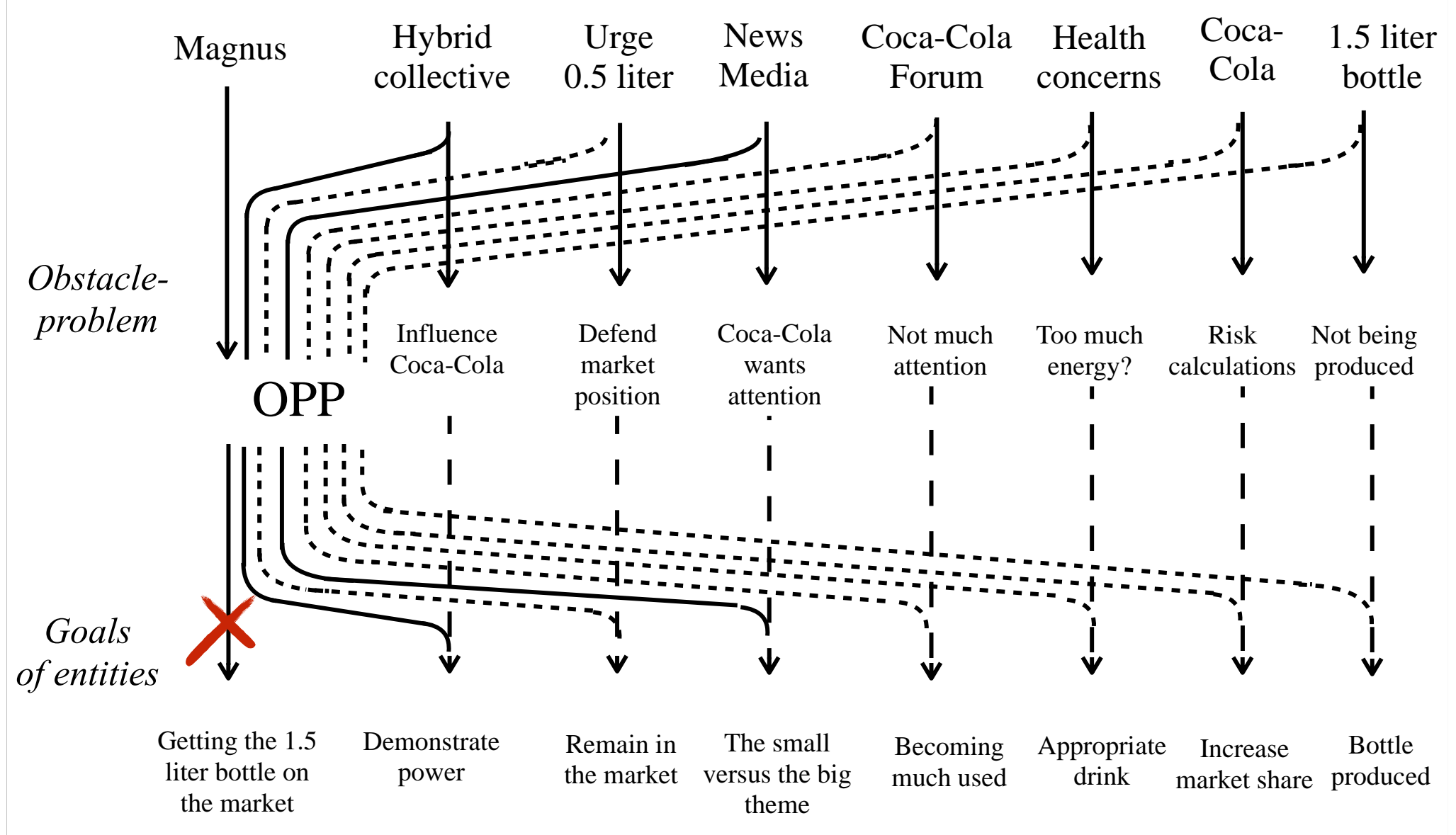

Figure 2: First - unsuccessful - translation process.

\section{Outcome}

Magnus successfully established a hybrid collective by intelligent use of the social media and ICT, mobilizing the press and became a spokesperson in his own community.

However, as shown in Figure 3, the hybrid collective failed to impress on senior management at Coca-Cola the seriousness and significance of the impact on their user forum and thus failed to convince Coca-Cola, where senior management was concerned rather with the 0.5 litre Urge bottle already on the market. Also, the health concerns and the risk calculation did not come out in favour of reinstating the 1.5 litre version of Urge: was it perhaps - but we can only guess at this - because management wanted to test the government reactions? Without all actors being enrolled in the network, it remained powerless and could not bring about the move to reinstate the 1.5 litre bottle on the market. 


\section{Second translation: the day of the Urge}

\section{Problematization}

Magnus's concern continued to be to convince Coca-Cola to produce the 1.5 litre Urge bottle. The Facebook group members saw Magnus as a legitimate spokesperson and they shared his goal: to prove to Coca- Cola that there was a real demand for Urge in the 1.5 litre format. A group member - Irvin, who collected all related articles from the press presented to Magnus the idea of organizing a "Big Urge Day" to demonstrate the purchasing power of the consumers. The goal of the Big Urge Day was to buy as much Urge as possible in one day throughout the whole of Norway. Coca-Cola faced health and profit dilemmas. The company had to consider the risks of producing the 1.5 litre Urge bottle vis-a-vis the health authorities' potential reactions and the impact on the sales profits for the existing 0.5 litre Urge. Their concern was also related to the retailers who monitored the sales and needed to have the shelf capacity in order to distribute the soft drink.

\section{Interessement}

Irvin's idea was taken up and the Big Urge Day was set for 19 May 2008, namely after the Norwegian national day on 17 May. The aim was to buy as many Urge bottles as possible, to signal that summer was coming and that people were happy because of that. Magnus wanted to demonstrate the power of the group, so he invited 100,000 people to take part in the "buy-cott" action. Days before the event, he started to spam Coca-Cola, writing "I demand that you listen to us and that you sell the product".

\section{Enrolment}

The Big Urge Day proved able to start the enrolment of all actors in the network and overcome resistance. The members of the social media group, the 0.5 litre Urge, the retailers, those concerned with health and the senior management of Cola-Cola were all made stable allies and began supporting Magnus and his quest.

Sales of the 0.5 litre bottle in a single day were double those of the previous year throughout the whole country. The retailers were enrolled by this event and came to realize that the demand for Urge was tangible. Retailers reported the positive attitude - 
and probably the sales numbers - to Coca-Cola. The Big Urge Day was considered a major event, spread around the whole of Norway. Magnus commented:

The director of Coca-Cola told me that most stores in Norway doubled their sales on Urge from the previous Monday and that particular day a lot of stores were just sold out, so at that point I think Coca-Cola realized the power. We were not just empty numbers. We were actually a lot of very engaged people that really wanted to have this back. So, it was like a demonstration that this is actually a real passion.

\section{Mobilization}

Magnus suggested that the group "buy-cott" instead of boycott: showing how much they were willing to consume a product that they loved, which had to be considered a better option than not buying at all. After the buy-cott action, the members started to post pictures of the group members buying or carrying home the entire supply of Urge they could find in the local stores. Many stores were left with completely empty shelves! According to Coca-Cola managers, this was the first positive buy-cott they had ever experienced, manifested in terms of buying huge quantities. The managers interpreted the action not as representing an expanding group, but as a shift in needs: for economic reasons and convenience, instead of buying three 0.5 litre bottles, the customers wanted a single 1.5 litre bottle because they needed more per head.

The group members, now numbering more than 30,000 supporters in a total market of 4.8 million consumers, started to call the Coca-Cola hotline and request that the 1.5 litre Urge be brought back to the market. Before the Big Urge Day, Coca-Cola had on average 10 calls per day and suddenly it was hundreds.

Sales numbers demonstrated the demand for the 1.5 litre Urge bottle and continued to make Magnus Nyborg a legitimate spokesperson. Coca-Cola made Magnus a "hero figure" for the brand and launched the bigger soft drink in September 2008. The controversy about the health concerns did not emerge. Magnus articulated the demands of the consumers and Coca-Cola supported the image of the "Urge hero", finally listening to Magnus's complaint. Concerns about the possibility that sales of the 0.5 litre bottle could decline by launching the 1.5 litre bottle were silenced in the process, backed by the high sales volumes on the Big Urge Day. 
According to the Coca-Cola operations manager, this was a very peculiar event. Coca-Cola was used to engaging in advertising and marketing campaigns and if someone had a complaint about a product, he/she simply would not buy it anymore. This event dragged Coca-Cola into the network and mobilized the company. The company agreed to re-introduce the 1.5 litre bottle. An issue that arose in Coca-Cola was the distribution channel: whether to distribute through any channel or only a few, so the risk would be contained. The options were tested through market research as Coca-Cola preferred to have a profitable 0.5 litre business rather than an unprofitable 1.5 litre business. The solution found was to advertise both, so Coca-Cola could both sell the 1.5 litre version and maintain the profitable 0.5 litre option. Convincing the distribution channels of these propositions and undertaking adequate campaigns took six months. As Coca-Cola did not want to put too much emphasis on the social media group members, it was decided not to communicate directly with them:

Because otherwise if I said to Magnus "we are going to launch this now", they would celebrate that as a victory, which would mean we would lose momentum in the launch. We saw the activity level in that group was very high, 0.5 litre sales continued to be very high and basically we were planning the launch to be a sort of "big bang" and get Magnus to taste the first bottle. (PR manager) 


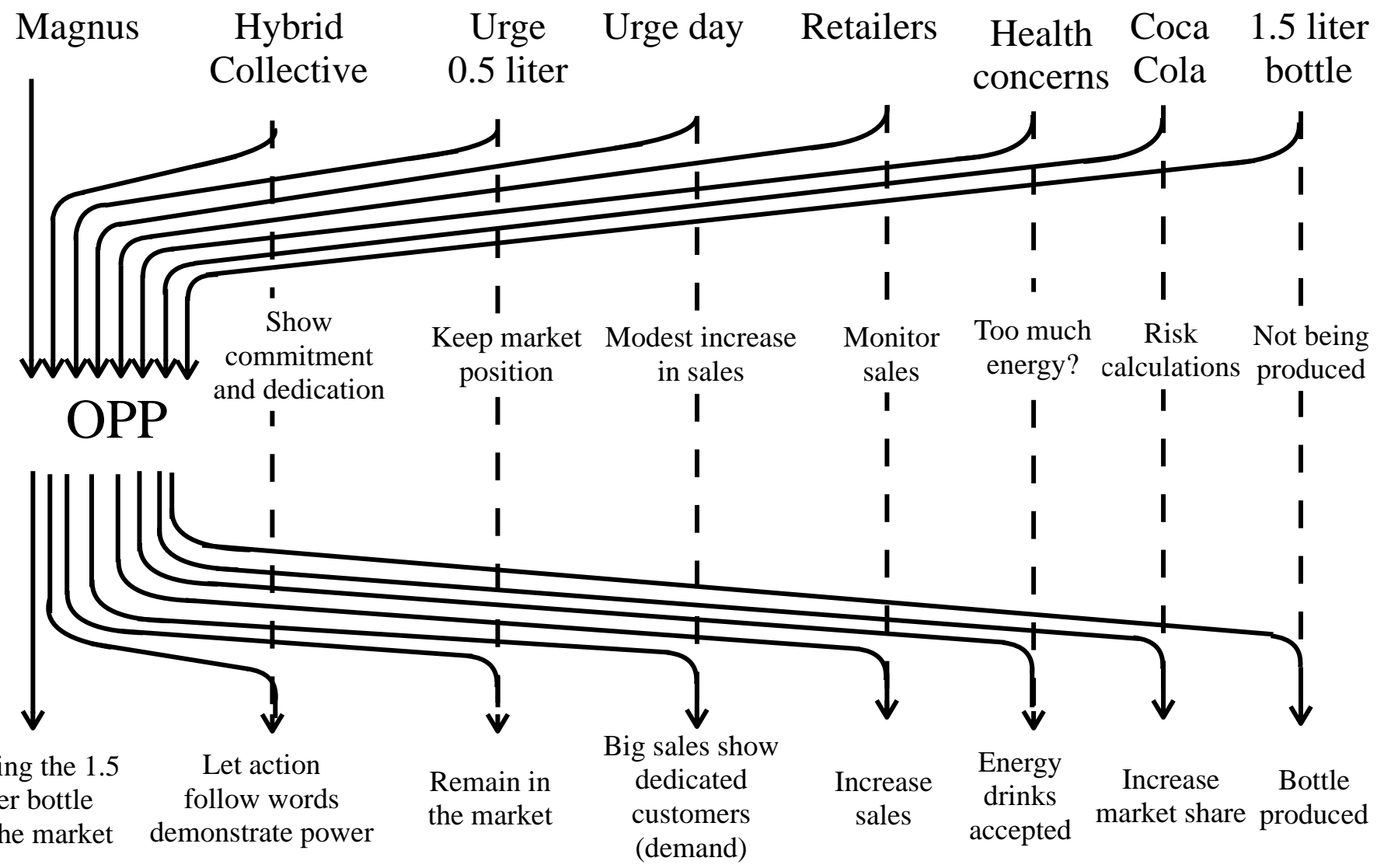

Figure 3: Second - successful - translation, bringing the 1.5 litre Urge bottle back to the market.

\section{Outcome}

The second translation is illustrated in Figure 3. Coca-Cola recognized Magnus as the spokesperson of the hybrid collective network supporting the re-introduction of the 1.5 litre bottle (http://www.nettavisen.no/1934876.html). Invited by Coca-Cola he flew over the fjeld to participate in the manufacturing of the first batch of the new version of Urge in Oslo. Magnus was also invited to taste the content of the bottles with the Coca-Cola testers. After this event, when the bottles had been introduced on the market, Magnus became known in Bergen as "the Urge guy".

Coca-Cola started to reinforce the feelings of victory in its marketing, disseminating messages of having been able to do something meaningful, a big corporation listening to the complaints of its customers and being challenged by a 
spokesperson for the Urge community. Coca-Cola communicated widely about the day a 17-year-old boy forced the company to change its marketing strategy.

Four months after the introduction of the 1.5 litre bottles of Urge on the market, sales of the larger bottles represented $81 \%$ of the market growth and $39 \%$ of the growth in revenue; at the same time, the 0.5 litre version still had very high sales, experiencing $195 \%$ volume growth and $58 \%$ revenue growth, without any investment in the marketing of the product.

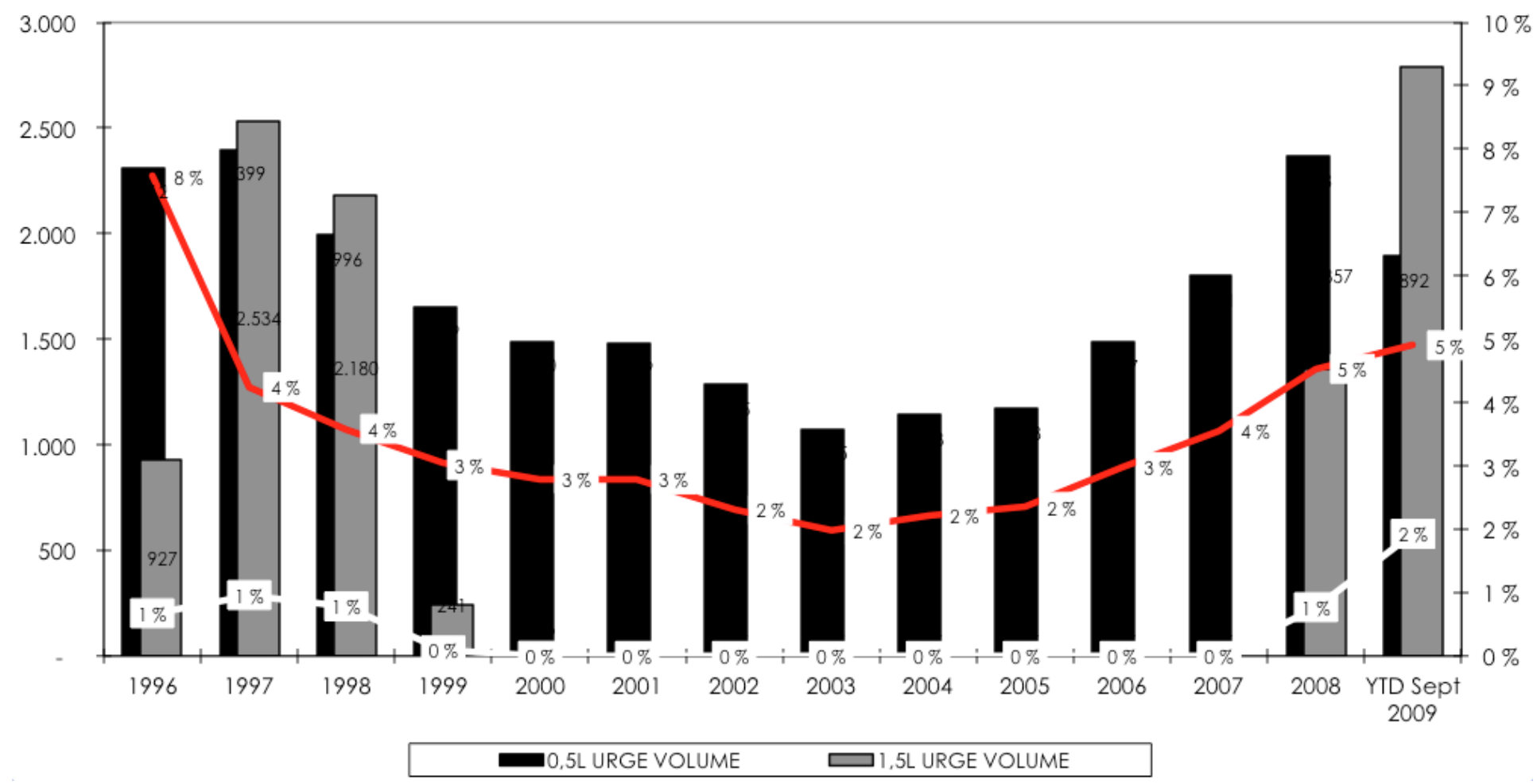

Figure 4: Retail sales figures for Urge 0.5 litre and 1.5 litre bottles in Norway.

\section{Third translation: new product launched}

\section{Problematization}

The goals of the soft drink company and Magnus easily melded together in this translation. Magnus remained the spokesperson for Urge, but the Coca-Cola company was the one that helped define a new OPP in order to protect its position and stay market leader. Being market leader and defending Urge from competitors became one and the 
same. Magnus was quick to accept the problematization and interessement and enrolment were collapsed into a single point in this situation. Urge sales were increasing without any additional marketing campaigns. The Norwegian parliament changed the legislation regarding soft drinks, permitting the sale of so-called energy drinks in Norway; this allowed the introduction of energy drinks like Red Bull to the market. Urge, as it appeared in the marketing campaigns, was already presented and used as a daytime energy drink.

At that point, Coca-Cola had a market presence with its energy drink "Burn" and had a local competitor called "Battery". The entry of Red Bull to the market would mean that Coca-Cola needed a comparable match. Coca-Cola, therefore, decided to exploit the Urge wave and launch a line extension. A new product had to be developed to stay in the energy drink segment. As the Urge brand was regarded as the right brand for its targeted segment, Coca-Cola decided to develop a new product under this category: market research indicated that consumers perceived Urge to be an energy brand, so Coca-Cola decided to develop a new product called "Urge Intense" - a daytime energy drink - and launch it a few months before Red Bull entered the market. The market research confirmed that Urge was the favourite brand for an energy drink in Norway at this time.

As Magnus Nyborg was THE spokesperson for the Urge brand, the company decided to involve him and some other Urge enthusiasts in the product development process of Urge Intense. The problematization thus becomes one in which the spokesperson Magnus is used, but not unwillingly, as the spokesperson to defend the Urge brand and support its position in the market.

\section{Interessement}

The rumours about Red Bull entering the Norwegian energy drink market, potentially threatening the position of Urge, and the upward trend in daytime energy drinks became interessement devices that re-invoked the network and the interessment of Magnus, the hybrid collective and Urge in both the 0.5 litre and 1.5 litre forms. The company was working in two directions at the same time: Magnus wanted to defend the Urge brand and hopefully help it expand; Coca-Cola wanted the Urge brand to expand its market size. The hybrid collective could use a refreshment of its ambitions and goals. Magnus 
acquired his power from the hybrid collective and was able to represent Urge as he was recognized by the hybrid collective - the mix of social media and its members and followers - as a legitimate spokesperson. To expand the network further, customers were invited to create graffiti in the centre of the capital, Oslo, announced as an Urge event and all members of the social media supporting Urge were invited to the big launch party for Urge Intense.

\section{Enrolment}

Coca-Cola's strategy was to involve what they called the Urge "core group" without hiring them. Magnus was easily enrolled in the new product development of Urge Intense and made responsible for selecting additional members of the user product development group; thus, he literally dragged the hybrid collective into Coca-Cola's corporate headquarters, which the hybrid collective had before that seized for such a long time. Magnus was not only the spokesperson for Urge, but also a very well-known snowboarder, well connected and by now considered a Norwegian trend-setter. The task presented to them by Coca-Cola was to develop a new product, to be launched under the Urge umbrella, with a similar taste, but a little more like Red Bull, more lemon-flavoured and closer to an energy drink.

\section{Mobilization}

The group of teenagers was involved in several stages of the new product development, such as tasting and deciding on the name, logo and packaging design. Urge Intense was developed using the teenagers' input. The group of ten Urge-lovers undertook blind tests: they agreed on the Urge Intense flavour they liked the most and this was the one finally chosen. The group agreed that they did not want a plastic bottle, but rather:

A can, that looks like a beer can, 0.5 litre, and the packaging should be a bit tribal, a bit graffiti-like, like a jungle, urban kind of feeling.

The prototype of Urge Intense was discussed among the group and Magnus later confirmed that the one chosen was the taste they all liked. Market research was conducted to assess if the $350 \mathrm{ml}$ or $500 \mathrm{ml}$ was preferable and it showed that the 
customers wanted the bigger can. Through this translation process, the Coca-Cola company was acknowledged, accepted and acted as a legitimate spokesperson in defending and expanding the market for Urge, while the hybrid collective and its legitimate spokesperson, Magnus, collaborated with the multinational company in this alliance.

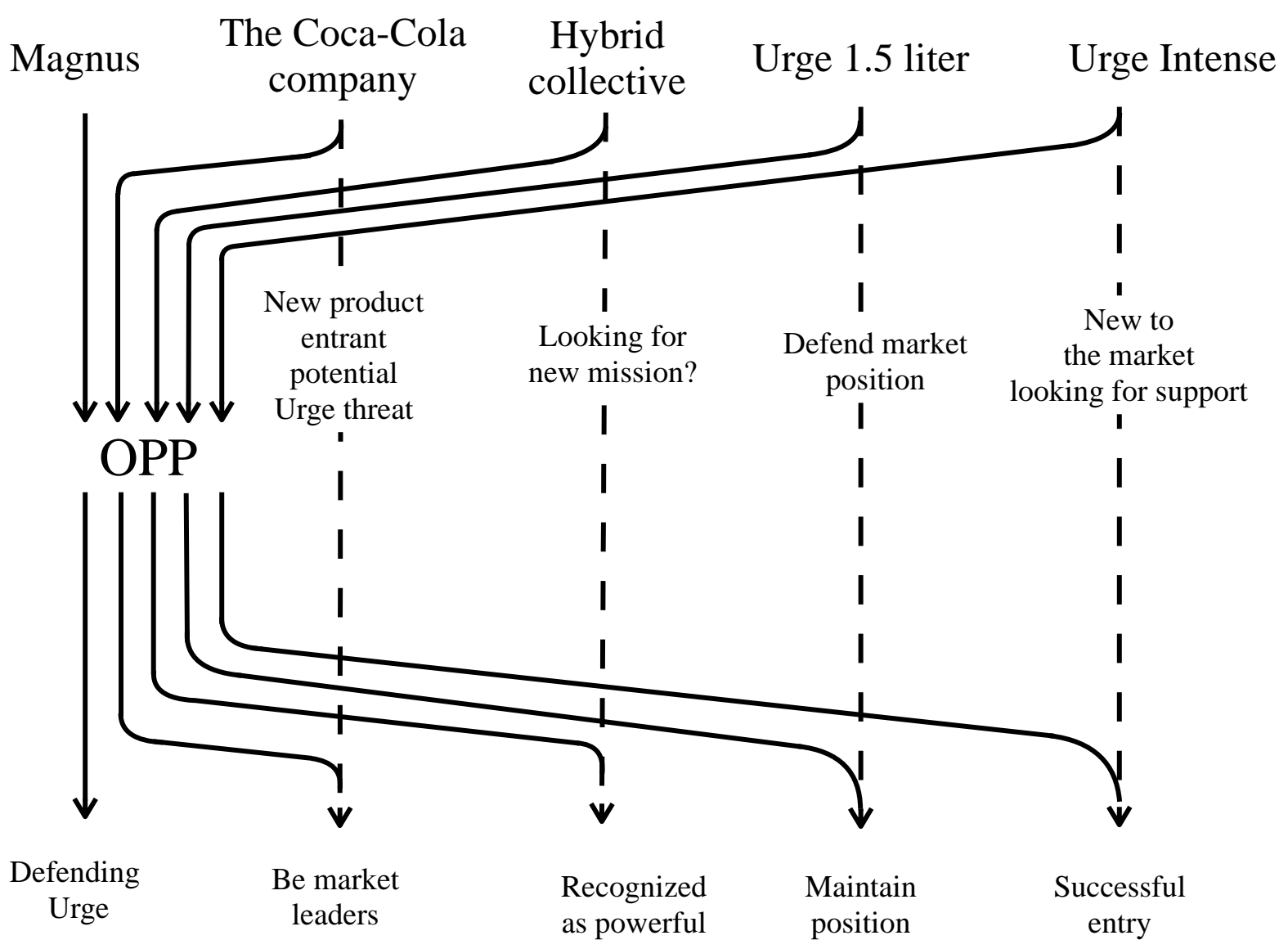

Figure 5:Third translation: Magnus, the hybrid collective and the company shares an OPP into which actors are translated willingly.

\section{Outcome}

As shown in Figure 5, Urge Intense was produced and Coca-Cola became the leading supplier in Norway with its two energy drinks: Urge Intense and Burn. Magnus successfully confirmed his role as a legitimate spokesperson for Urge. The hybrid collective and the company formed a strong alliance that successfully defended "their" 
product from evil entrants. Coca-Cola not only stayed in the energy drink market and became market leader with its two drinks, but also saw this market become one of the few in which the company was a leader in energy drinks, having $43 \%$ of the market share.

\section{DISCUSSION}

The case presents a complaining customer who did not withdraw his support and deprive the company of some portion of his income, but who opted for the "voice" strategy (Hirschman, 1970). Much more than that, he managed to inspire the creation of a hybrid collective, which not only echoed his complaint but also amplified it so that it gained national attention. This part illustrates how voice requires the customer to be engaged in a controversy, an open act of showing one's disagreement with the order of things and moving out of the normal comfort zone.

Customer complaints as sources of innovation have been treated before (Fornell and Wernerfelt, 1987, 1988) and can be regarded as an alternative or supplement to deliberate innovation search strategies (Henttonen and Ritala, 2013), but also, going beyond the findings of Henttonen and Ritala (2013), extending the range of possible strategies that can be used to stimulate innovation. The observations made here also contribute to the perspective that has presented "lead users" as those who produce solutions (von Hippel, 1986). We suggest that there might be a category of leading complaining users who produce useful and inspiring complaints.

Lead users propose a way of solving a problem because they will benefit significantly by obtaining a solution to their own needs (Von Hippel, 1986, p. 796). The complaining users presented here also represent users who are ahead of the market trend and they would also benefit greatly from the "solution", in this case the introduction of the desired product. They require it, but they do not possess the capabilities or technical means to create the prototype; instead, they can raise their voices and complain, but they can also mobilize others via the formation of a hybrid collective. Lead users are described as highly innovative and an important resource for companies (Von Hippel, 1986), but to be successful, the lead user also needs a company 
that does not show resistance (Lilien et al., 2002). The strength of the complaining user who successfully translates others into the network and the hybrid collective is that his/her powers grow enormously and can match those of global corporations. So, in contrast to the single creative lead user, the spokesperson and the hybrid collective are together quite powerful, but could also be treacherous partners if not treated with respect.

The analysis of the three translation processes provides insights into how the hybrid collective was formed, based on the problematization suggested by one complaining customer, managing to increase - double, triple and re-double - the number of actors. This not only made for more supporters, but also made possible participation in the mobilization that ultimately provided the hybrid collective with its powers. The hybrid collective becomes more than the sum of those involved, by its ability to multiply relations, stimulate collective action and finally develop a type of distributed collective cognition (Hutchins, 1995). Collective cognitions might be brought about by design, but in-depth studies seem to reveal that the process might emerge and become effective before any of the participants themselves realizes it (Hutchins, 1995). This is one of the processes that give the hybrid collective its strength. In the latter two translations presented here, Magnus - the spokesperson - becomes smarter and wiser than he is on his own, for example by receiving intelligent suggestions on how to frame the Big Urge Day so that it becomes a positive manifestation ("buy-cott") rather than a negative one (boycott).

In this case, the powers of the hybrid collective - after one not so successful attempt - became capable of a mobilization producing actions that finally made the global company listen and overcome its fears of taking a risk by (re)introducing a new product type that might have threatened an existing product and engendered health concerns. The power of the network, the alliances formed and the hybrid collective required several translations before its strength was recognized and the initiator, the Urge lover, the skateboarder, the Facebook group founder, the social entrepreneur and rebel Magnus, became a legitimate spokesperson. Although it has recently been suggested that the most important movement in innovation is the choice of a good spokesperson and the interessement (Akrich et al., 2002a, 2002b), this case indicates that the ability to 
demonstrate action, e.g. the mobilization, might in some instances be the most critical movement. The strength of the hybrid collective was dependent on the many alliances made through accepting the problematization, the successful interessement and the enrolment of both human and non-human actors, but its power first became evident when the collective was able to demonstrate its ability to move things: the mobilization of consumers to write protests, invite others to join, make phone calls and eventually go to stores to make purchases, empty the shelves and engage the media. The hybrid collective, understood as a network of human and non-human actors and information technologies (Callon, 2004), helps us to change the focus from the individual actor to the coordinated collective action. The spokesperson of the group communicates through the online communities, reaching different places at the same time, holding together a physically distributed network: Actors, users, consumers, complaints, supporters, messages and conversations are no longer restricted to a certain geographic area. Also, the non-human actors play an active role in shaping the network. The hybrid collectives are not only enablers, but also enhancers of speed by overcoming distances in time and space and expanding the ways in which it is possible to demonstrate consumer power. Such a use of technologies and hybrid collectives empowers customers and potentially increases their influence on the design and survival of products and even company strategies (Callon, 2004; Christiansen et al., 2010).

We do not claim to generalize these observations beyond the single case, but we find that it represents an illustration of some mechanisms that can advance our knowledge on the role of complaining customers in product development. Single depth single case studies are often strong in developing insights into processes that that are not easily revealed in large-scale surveys (Flyvbjerg, 2001), but we are not claiming that these processes are general. Other studies have to confirm this. Besides, researching networks and hybrid collectives, based on a large distributed network of (mostly very) loosely connected members is a challenge, and could require more resources if we wanted to know even more about the ongoing social processes. The focus of the present study, has allowed the available resources to be sufficient to analysis and report on an appropriate level of details for the purpose set here. However, all studies, also those based on the present theoretical framework is based on the authors ability to present a 
coherent and convincing analysis, with relevant constructs and arguments, as Latour (2005, p. 122) puts it, 'We write texts, we don't look through some window pane".

\section{CONCLUSION}

Understanding how innovation happens as complaining users mobilize from using the concept of hybrid collectives makes it possible to explore the relationship between customers, complaints and product and innovation processes. Complaints are turned into a positive product development process through constant negotiations between the human and non-human actors and the alliances between them. The outcome is a co-constructed product. In this paper, we have also added the concept of the complaining user who becomes a spokesperson. Instead of exiting the relationship, as expected in marketing and economics theories, the complaining user uses his voice differently as he cries out on social media, making this technology an ally in the quest, in asking for debate, answering questions and demanding actions from the company, supported by other customers successfully enrolled into his network of alliances.

In the literature on product development and innovation, different approaches have been investigated considering the role of lead users and online communities, but little attention has been paid to the issue of activated users, actors who try to mobilize and aggregate their complaints. The role of hybrid collectives and emerging collective cognition for the mobilization of large groups of actors/consumers needs to be investigated further.

An important implication for companies and managers involved in product development and marketing - and one that is sparsely researched - is the need for training to listen to and involve complaining users. Such competencies in companies will make it possible to tap into wild and heterogeneous sources of knowledge and inspiration. To exploit the voice of unhappy customers and the potential of relationships with hybrid collectives fully, companies need to develop their absorptive capabilities and a corporate culture that invites a broader dialogue with customers, recognizing that there might indeed be very profitable innovations hidden behind a complaint. Besides, the ability to 
negotiate and make alliances with these angry spokespersons and hybrid collectives might determine consumers' faith in products and firms.

\section{REFERENCES}

Akrich, M (1992). The de-scription of technical objects. In W. Bijker and J. Law (Eds.) Shaping Technology/Building Society: Studies in Sociotechnical Change. Cambridge, MA: The MIT Press, 205- 224.

Akrich, M and Lemonnier, P (1993). Essay of technosociology: A Gasogene in Costa Rica. In P. Lemonnier (Ed.) Technological Choices. Transformation in Material Cultures since the Neolithic. London, UK: Routledge, London, 289-337.

Akrich, M, Callon, M, and Latour, B (2002a). The key to success in innovation part I: The art of interessement. International Journal of Innovation Management, 6(2), 187-206.

Akrich, M, Callon, M, and Latour, B (2002b). The key to success in innovation part II: The art of choosing good spokespersons. International Journal of Innovation Management 6(2), 207-225.

Anderson, E W, Fornell, C, and Lehmann, D R (1994). Customer satisfaction, market share, and profitability: Findings from Sweden. The Journal of Marketing, 58(3), 53-66.

Baron, S and Warnaby, G(2011). Individual customers' use and integration of resources: Empirical findings and organizational implications in the context of value cocreation, Industrial Marketing Management, 40(2), 211-218.

Bentzen, M E, Christiansen, J K, and Varnes, C J (2011). What attracts decision makers' attention? Managerial allocation of time at product development portfolio meetings. Management Decision, 49(3), 330-349.

Bilgram, V, Brem A, and Voigt, K I (2008). User-centric innovations in new product development systematic identification of lead users harnessing interactive and collaborative online-tools. International Journal of Innovation Management, 12(3), 419-458. 
Brockhoff, K (2003). Customers' perspectives of involvement in new product development. International Journal of Technology Management, 26(5), 464-481.

Calantone, R J, Benedetto, C A, and Haggblom, T (1995). Principles of new product management: Exploring the beliefs of product practitioners. Journal of Product Innovation Management, 12(3), 235-247.

Callon, M (1986). The sociology of an actor-network: The case of the electric vehicle. In Callon, M, Law, J and Rip, A (Eds.) Mapping the dynamics of science and technology. London, UK: Macmillan. 19-34.

Callon, M (1986b). Some elements of a sociology of translation: Domestication of the scallops and the fishermen of St Brieuc Bay. In J. Law (Ed.) Power, Action and Belief: A New Sociology of Knowledge? London, UK: Routledge and Kegan Paul, 196-233.

Callon, M. (1987). Society in the making: The study of technology as a tool for sociological analysis. In T. J. Pinch (Ed.) The Social Construction of Technological Systems. New Directions in the Sociology and History of Technology. Cambridge, MA: MIT Press, 83-103

Callon, M (2004). The role of hybrid communities and socio-technical arrangements in the participatory design. Journal of the Center for Information Studies, 5(3), 3-10.

Callon, M and Law, J (1982). On interests and their transformation: Enrolment and counter-enrolment. Social Studies of Science, 12(4), 615-625.

Callon, M and Muniesa, F (2005). Economic markets as calculative collective devices. Organization Studies, 26(8), 1229-1250.

Callon, M, Méadel, C, and Rabeharisoa, V. (2002). The economy of qualities. Economy and Society, 31(2), 194-217.

Chassagnon, V and Audran, M (2011). The impact of interpersonal networks on the innovativeness of inventors: From theory to empirical evidence. International Journal of Innovation Management, 15(05), 931-958.

Christiansen, J K and Varnes, C J (2007). Making decisions on innovation: Meetings or networks? Creativity and Innovation Management, 16(3), 282-298. 
Christiansen, J K, Varnes, C J, Hollensen, B, and Blomberg, B C (2009). Co-constructing the brand and the product. International Journal of Innovation Management, 13(03), 319-348.

Christiansen, J K, Varnes, C J, Gasparin, M, Storm-Nielsen, D, and Vinther, E J (2010). Living twice: How a product goes through multiple life cycles. Journal of Product Innovation Management, 27(6), 797-827.

Daymon, C and Holloway, I (2011). Qualitative Research Methods in Public Relations and Marketing Communications. Oxon, UK, Routledge.

Flyvbjerg, B. (2001). Making social science matter: Why social science fails and how it can succeed again. Cambridge: Cambridge University Press.

Fornell, C and Wernerfelt, B (1987). Defensive marketing strategy by customer complaint management: A theoretical analysis. Journal of Marketing Research, 24, 337-346.

Fornell, C and Wernerfelt, B (1988). A model for customer complaint management. Marketing Science, 7(3), 287-298.

Fuchs, C and Schreier, M. (2011). Customer empowerment in new product development. Journal of Product Innovation Management, 28(1), 17-32.

Füller, J and Matzler, K (2007). Virtual product experience and customer participation: A chance for customer-centred, really new products. Technovation, 27(6-7), 378387.

Goetzinger, L, Park, J K, and Widdows, R (2006). E-customers' third party complaining and complimenting behavior. International Journal of Service Industry Management, 17(2), 193-206.

Hansen, T, Wilke, R, and Zaichkowsky, J (2010). Managing consumer complaints: Differences and similarities among heterogeneous retailers. International Journal of Retail \& Distribution Management, 38(1), 6-23.

Hart, C W, Heskett, J L, and Sasser, W E (1990). The profitable art of service recovery. Harvard Business Review, 68(4), 148-156.

Henttonen, K and Ritala, P (2013). Search far and deep: Focus of open search strategy as driver of firm's innovation performance. International Journal of Innovation Management, 17(03), 1340007-1-1340007-20. 
Hirschman, A O (1970). Exit, Voice, and Loyalty: Responses to Decline in Firms, Organizations, and States. Cambridge, MA: Harvard University Press.

Homburg, C and Fürst, A (2005). How organizational complaint handling drives customer loyalty: An analysis of the mechanistic and the organic approach. Journal of Marketing, 69(3), 95-114.

Hutchins, E. (1995). Cognition in the Wild. Cambridge, Mass.: MIT Press.

Jeppesen, L. B. (2005). User toolkits for innovation: Consumers support each other. Journal of Product Innovation Management, 22(4), 347-362.

Knorr Cetina, K (1999). Epistemic Cultures: How the Sciences Make Knowledge. Harvard University Press: Cambridge, Mass.

Lagrosen, S (2005). Customer involvement in new product development. European Journal of Innovation Management, 8(4), 424-436.

Latour, B (1987). Science in Action: How to Follow Scientists and Engineers through Society. Cambridge, Massachusetts: Harvard University Press.

Latour, B (2005). Reassembling the Social: An Introduction to Actor-Network-Theory. New York: Oxford University Press.

Leonard-Barton, D (1995). Wellsprings of Knowledge: Building and Sustaining the Sources of Innovation. Boston, Mass.: Harvard Business School Press.

Lilien, G L, Morrison, P D, Searls, K, Sonnack, M, and von Hippel, E (2002). Performance assessment of the lead user idea-generation process for new product development. Management Science, 48(8), 1042-1059.

Nambisan, S (2002). Designing virtual customer environments for new product development: Toward a theory. Academy of Management Review, 27(3), 392-413.

Plymire, J (1991). Complaints as opportunities. Journal of Consumer Marketing, 8(2), $39-43$.

Sawhney, M and Prandelli, E (2000). Communities of creation: Managing distributed innovation in turbulent markets. California Management Review, 42(4), 24-54.

Schuhmacher, M C. and Kuester, S (2012). Identification of lead user characteristics driving the quality of service innovation ideas. Creativity and Innovation Management, 21(4), 427-442. 
Stauss, B and Schoeler, A (2004). Complaint management profitability: What do complaint managers know? Managing Service Quality, 14(2/3), 147-156.

Von Hippel, E (1978). Successful industrial products from customer ideas. The Journal of Marketing, 42(1), 39-49.

Von Hippel, E. (1986). Lead users: A source of novel product concepts. Management Science, 32(7), 791-805.

Ward, J C and Ostrom, A L (2006). Complaining to the masses: The role of protest framing in customer-created complaint web sites. Journal of Consumer Research, 33(2), 220-230.

Yin, R. K. (2009). Case Study Research: Design and Methods. London: Sage Publications.

Zairi, M (2000). Managing customer dissatisfaction through effective complaints management systems. The TQM Magazine, 12(5), 331-337 